\title{
Differences in the quality of life dependent on family status of the elderly living in rural areas - a cross-sectional survey
}

\author{
Paweł Chruściel ${ }^{1, A-F}$, Katarzyna Małgorzata Szczekala, D-E, Tomasz Derewiecki, ${ }^{3, E}$, \\ Klaudia Jakubowska, ${ }^{1, C, E}$, Dorota Nalepa ${ }^{4, C, E}$, Marta Ewa Czekirda ${ }^{5, C, E}$, Violetta Mianowana1,C,E, \\ Magdalena Czarkowska ${ }^{6, E-F}$ \\ ${ }^{1}$ Department of Basic Nursing and Medical Teaching, Chair of Development in Nursing, Faculty of Health Sciences, \\ Medical University, Lublin, Poland \\ ${ }^{2}$ Department of Foreign Languages, I Faculty of Medicine with Dentistry Division, Medical University, Lublin, Poland \\ ${ }^{3}$ Department of Physiotherapy, University of Management and Administration, Zamosc, Poland \\ ${ }^{4}$ Faculty of Social Sciences and Humanities, State Higher Vocational School Memorial of Prof. Stanisław Tarnowski, \\ Tarnobrzeg, Poland \\ ${ }^{5}$ Faculty of Health Sciences, University of Economics and Innovation, Lublin, Poland
}

${ }^{6}$ Institute of Rural Health, Lublin, Poland

A - Research concept and design, B - Collection and/or assembly of data, C - Data analysis and interpretation,

$D$ - Writing the article, $E$ - Critical revision of the article, $F$ - Final approval of article

Chruściel P, Szczekala KM, Derewiecki T, Jakubowska K, Nalepa D, Czekirda ME, Mianowana V, Czarkowska M. Differences in the quality of life dependent on family status of the elderly living in rural areas - a cross-sectional survey. Ann Agric Environ Med. 2018 ; 25 (3): 532-538. doi: $10.26444 /$ aaem/93501

\section{Abstract}

Introduction. A factor that conditions the perception of the quality of life (QoL) is having a social network and relationships within it. The quality of life of seniors is assumed to be at a higher level if they are surrounded by those close to them in comparison to those living alone. The aim of the study was to assess differences in the quality of life of elderly rural residents depending on their family status.

Materials and method. Due to the random and mixed selection of respondents, the study comprised a group of 588 representatives living in rural areas of Eastern Poland. The differentiated criterion of the groups of senior respondents was their family situation: living with a family or living alone. Assessment of the quality of life was conducted by means of the WHOQoL-bref questionnaire. The Mann-Whitney tests and Kruskal-Wallis tests were used to carry out statistical analysis of the data.

Results. The respondents who lived with their families differed statistically to a significant extent $(p<0.005)$ from those who lived alone. The former gave a better assessment of the majority of the QoL domains: physical, psychological and social. Obtaining higher mean values for the environmental domain among the respondents living alone $(M=14.31)$ seemed to be an atypical and interesting phenomenon because seniors living with their relatives usually assessed that dimension better than those living alone.

Conclusions. The family situation of seniors affected the level of quality of life. Living with their relatives may be expected to be favourable for seniors because it translates into better performance in physical, psychological and social domains. Loneliness, which frequently accompanies old age, leads to the deterioration of the quality of life.

\section{Key words:}

quality of life, family, elderly, loneliness

\section{INTRODUCTION}

Old age is a period of life in which the health condition significantly determines the possibility of independent functioning. Moreover, aging results in physiological changes of functioning and affects the subjective perception of seniors' social situation, as well as their quality of life (QoL). The theoretical considerations of this study focus on the issue of the quality of life understood in a dual way, namely in the following two dimensions: objective and subjective [1-3]. The quality of life is a multifaceted construct of a non-uniform

Address for correspondence: Paweł Chruściel, Medical University of Lublin, Department of Basic Nursing and Medical Teaching, Chair of Development in Nursing, 4/6 Staszica 20-093 Lublin, Poland

e-mail: pawelchrusciel@o2.pl

Received: 11.05.2018; accepted: 16.07.2018; first published: 06.08.2018 character and lacking precisely determined theoretical bases. Therefore, definitions of the QoL are diversely formed, although they share one feature of emphasizing the subjective dimension dependent on different circumstances, with health condition being the central and key point of reference [4, 5]. A special and specific type of QoL is the Health Related Quality of Life (HRQoL). This has been created along with the development of a holistic trend in medicine and assesses the extent to which a disease and concomitant changes influence a patient's performance in his or her different areas of life [6-8]. Regarding a contemporary definition of health, the HRQoL refers to it's three dimensions:

1) physical (e.g. perceiving one's own corporeality, character of pain, necessity for taking drugs);

2) psychological (e.g. emotions, mental fitness, self-esteem; 3) social (e.g. interpersonal relations, fulfilling social roles) $[9,10]$. 
The QoL perceived in this way constitutes an essential element describing the state of health correlated with subjective experiencing of disease. The HRQoL becomes part of the definition of health as an important indicator that should be taken into account on an equal basis with medical indicators of health. The HRQoL belongs to a group of specific definitions that are concentrated on the subjective approach to the QoL. Currently, in medical sciences, specific definitions are the most common point of reference in which better health self-assessment is identified with better QoL. Furthermore, the HRQoL can be considered not only in the context of health and disease but also as a consequence of the natural process of aging. Such an assessment of QoL is believed to be the most useful and reliable for research purposes [11]. When examining the HRQoL of the elderly, a wide spectrum of determinants of health, physical and mental state, as well as social performance should be taken into account [12-15]. The relationship that occurs between the QoL and health is assumed to be multilateral since disturbance of one of its spheres contributes to irregularity in the remaining ones. One of the factors that conditions the perception of the QoL is having a social network and the resulting relationships [16-18].

It is the family that constitutes the original and fundamental source of support in health and sickness. The QoL of a senior surrounded by his or her relatives is assumed to stay at a higher level than that of a lonely senior. Moreover, the elderly living in rural areas more frequently experience psychological, social or somatic consequences of loneliness than those in urban areas [19]. The research proves that seniors from rural areas are characterized by a higher level of social alienation [20]. Current demographic and epidemiological trends are causing some changes in the household structure. Furthermore, the number of seniors living alone, particularly women, is increasing as a result of an earlier male mortality rate, and female longevity. Households usually consist of one person, usually a widow, aged over 80 years old. A considerable part of the senior population experience loneliness to various degrees, which constitutes a variable modifying the QoL, state of health or mental activity [21-23]. Another factor intensifying social isolation is associated with the 'empty nest' syndrome when children become independent and leave home. The process has consequences in the emotional dimension, mainly in mothers who perceive the situation as a loss. Apart from some typical signs of 'empty nest' syndrome, such as sadness, emptiness or loneliness, there are changes in the structure and size of the fundamental support system. A greater distance between the children's home and the family home frequently becomes a serious impediment to maintaining direct contact with their parents. It is worth mentioning that regardless of changing household structures and role of the family, an informal support structure at their place of residence most frequently becomes the source of support for seniors. A natural process of a gradual decrease or even loss of social networks deepens the sensation of emotional loneliness, and not infrequently predisposes seniors to commence institutional care. In many cases, loneliness is intensified by the death of a partner, the period of mourning, or the weakening of direct contact with family members [24-26]. Therefore, assessment of the HRQoL in the context of a senior's family situation becomes an indicator of his or her needs, as well as of his or her psychological and social functioning.

\section{OBJECTIVE}

The study was undertaken to assess differences in the quality of life depending on the family status of seniors living in rural areas.

\section{MATERIALS AND METHOD}

The study comprised a representative sample of 588 respondents living in rural areas of Eastern Poland. The respondents were randomly chosen by means of a mixed selection scheme: stratified non-returnable and systematic sampling. The scheme applied facilitated a quantitative and qualitative selection of counties in Eastern Poland and follow-up contact with the respondents according to the interpersonal interval $(k=36)$. The respondents were divided into the following two groups:

a. group A - respondents living with their families;

b. group B - respondents living alone.

Each respondent met all the criteria assumed to participate in the survey: being over 60 years of age, living in rural areas, having unimpaired cognitive functions, and giving written consent to take part in the study.

A quantitative strategy chosen for the study was a cross-sectional diagnostic survey. The WHOQoL-bref questionnaire compiled by experts of the World Health Organisation Quality of Life Group (WHOQoL Group) was used to assess the quality of life. This constitutes a shorter version of the WHOQoL-100 scale enabling determination of the subjective quality of life in both healthy and ill people. The scale created was based on the concept of the QoL as the perception of one's life situation in the context of cultural conditions and the system of values connected to one's goals, standards and expectations [27-30].The scale is characterized by psychometric parameters proved to a high degree and the instrument allows for the collecting of reliable information on the HRQoL. The questionnaire consists of 26 questions referring to the following elements of the QoL:

a. self-assessment of overall quality of life (OQoL);

b. self-assessment of an individual's state of health (ISH);

c. physical domain (PHD);

d. psychological domain (PSD);

e. social domain (SOD);

f. environmental domain (END).

The questionnaire responses are based on a five-point Likert scale ( 1 - the highest level of dissatisfaction, 5 - the highest level of satisfaction). The WHOQoL-bref data analysis is performed by computing the arithmetic mean of the responses regarding a particular domain after previously inverting the values of the responses numbered 3, 4 and 26 . To obtain scores comparable to those of the WHOQoL-100 questionnaire, the arithmetic mean values calculated should be transformed, namely multiplied by 4 . The questions numbered 1 and 2 are analyzed separately. Points for functioning domains range from 4-20, while those for questions 1 and 2 are from 1-5. The higher the number of points, the better the quality of life of a respondent. The application of the aforementioned questionnaire was authorized by the authors of the instrument. The choice of the questionnaire was dictated by its availability and the 
possibility of comparing the research results of the authors of the current study with those obtained by other authors. Moreover, a standardized questionnaire ensures a uniform way of measurement and minimizes potential dependence of results on researchers' interference. The WHOQoL questionnaire constitutes a universal and reliable tool for QoL assessment, also in the population of the elderly. Furthermore, the scale is characterized by psychometric parameters confirmed to a high degree (Cronbach's alpha coefficient of 0.69-0.81 depending on a domain). A short questionnaire compiled by the authors of this study was also used to collect demographic data. It was designed to allow the respondents to complete it on their own. The study was approved by the Bioethics Committee of the Medical University of Lublin (KE-0254/86/2015). Demographic diversity of the respondents is presented in Table 1 .

Table 1. Demographic variables in the groups

\begin{tabular}{llcccc}
\hline \multirow{2}{*}{ Variable } & & \multicolumn{2}{c}{ Group A $(\mathrm{n}=303)$} & \multicolumn{2}{c}{ Group B $(\mathrm{n}=285)$} \\
\cline { 2 - 6 } Gender & $\mathrm{N}$ & $\%$ & $\mathrm{n}$ & $\%$ \\
\hline \multirow{3}{*}{ Age } & Female & 199 & 65.7 & 167 & 58.6 \\
\cline { 2 - 6 } & Male & 104 & 34.3 & 118 & 41.4 \\
\hline \multirow{3}{*}{ Education } & $60-74$ & 205 & 67.7 & 153 & 53.7 \\
\cline { 2 - 6 } & $\geq 75$ & 98 & 32.3 & 132 & 46.3 \\
\hline \multirow{3}{*}{ Marital status } & Primary & 34 & 11.2 & 34 & 11.9 \\
\cline { 2 - 6 } & Vocational & 83 & 27.4 & 77 & 27.0 \\
\cline { 2 - 6 } & Secondary & 132 & 43.6 & 96 & 33.7 \\
\cline { 2 - 6 } & Higher & 54 & 17.8 & 78 & 27.4 \\
\cline { 2 - 6 } & Single & 25 & 8.3 & 124 & 43.5 \\
\cline { 2 - 6 } & Married & 202 & 66.7 & 0 & 0.00 \\
\cline { 2 - 6 } & Divorced & 25 & 8.3 & 59 & 20.7 \\
\cline { 2 - 6 } & Widowed & 51 & 16.8 & 102 & 35.8 \\
\hline
\end{tabular}

Statistical analyses. The variables analyzed had a qualitative character. Lack of normality of the distribution of variables (verified by means of the Kolmogorov-Smirnov test) and disturbances of equinumerocity in the groups (verified by a chi-squared test) were the bases for the application of non-parametric tests. To compare the two groups, the Mann-Whitney test was used. Each test was supplemented with calculation of the range coefficient of Glass' biserial correlation $(\mathrm{rg})$ as a measure of the strength of the differences in effect. Differences among three and more groups were verified by the Kruskal-Wallis test supplemented with post hoc Dunn's explanatory analyses, together with Bonferroni correction. For each statistic of the Kruskal-Wallis tests, coefficient of effect size $\eta^{2}$ was calculated. Statistical analyses were performed using IBM SPSS Statistics 23. Statistically significant results accepted were $\mathrm{p} \leq 0.05$.

\section{RESULTS}

Depending on the respondents' family situation, six elements of the WHOQoL-bref questionnaire were analyzed. The highest difference of mean values was found in the majority of variables for group A: self-assessment of overall quality of life, self-assessment of an individual's state of health, physical domain, psychological and social domains. The exception is a worse assessment of the environmental domain in the group of respondents living with their families. This is an atypical situation because these seniors usually assess the dimension as better than those who live alone. The physical domain was highly rated by group $A$ while the environmental one by group B (Tab. 2). Statistical analyses revealed that the respondents living with their families (group A) were statistically different from $(\mathrm{p}<0.005)$ the respondents living alone (group B). The differences, although weak, concerned quality of life and all its components $(r g>0.3)$ indicating that the group A respondents provided a better evaluation of all the domains of the QoL discussed.

As mentioned above, higher mean values for the environmental domain in the group of seniors living alone $\left(M_{A}=13.63\right.$ vs. $\left.M_{B}=14.31\right)$ constitute an atypical and interesting phenomenon. Moreover, this is one of the highest disproportions between the mean values analyzed (0.68). Detailed analysis of the nonparametric tests is presented in Table 2.

Table 2. Comparison of QoL results between the groups

\begin{tabular}{lccccccccc}
\hline \multirow{2}{*}{ Variable } & \multicolumn{3}{c}{ Group A $(\mathrm{n}=303)$} & \multicolumn{4}{c}{ Group $\mathrm{B}(\mathrm{n}=285)$} & \multicolumn{3}{c}{ M-W test } \\
\cline { 2 - 10 } & $\mathrm{M}$ & $\mathrm{SD}$ & $\mathrm{Me}$ & $\mathrm{M}$ & $\mathrm{SD}$ & $\mathrm{Me}$ & $\mathrm{Z}$ & $\mathrm{p}$ & $\mathrm{rg}$ \\
\hline OQoL & 3.62 & 0.73 & 4.00 & 3.35 & 0.85 & 3.00 & -5.159 & 0.000 & 0.17 \\
\hline ISH & 3.30 & 0.89 & 3.00 & 3.18 & 0.96 & 3.00 & -2.182 & 0.029 & 0.07 \\
\hline PHD & 14.85 & 2.55 & 15.43 & 14.30 & 2.56 & 13.71 & -3.133 & 0.002 & 0.11 \\
\hline PD & 13.47 & 2.58 & 13.33 & 13.02 & 2.79 & 12.00 & -2.761 & 0.006 & 0.08 \\
\hline SD & 14.22 & 2.44 & 14.67 & 13.79 & 2.35 & 13.33 & -2.676 & 0.007 & 0.09 \\
\hline ED & 13.63 & 1.85 & 13.50 & 14.31 & 2.43 & 14.00 & -2.801 & 0.005 & -0.16 \\
\hline
\end{tabular}

M - mean; SD - standard deviation; Me - median; M-W test - Mann-Whitney test; $r g$ - Glass rank-biserial correlation

Comparative tests, namely the Mann-Whitney U test and Kruskal-Wallis test, were performed in order to investigate the influence of demographic variables on the perception of QoL (Tab. 3, 4 and 5). First, the impact of the respondents' gender and age on their QoL was analyzed. The MannWhitney test confirmed a differentiative influence of gender only in the scope of health self-assessment $(p=0.007)$. Females were characterized by higher values in the aforementioned domain. Measurement of size effect of $r g$ differences indicated differentiation of low intensity $(r g>0.3)$. The respondents aged 60-74 years old gave a better assessment of every aspect of QoL $(\mathrm{p}<0.001)$ and intensity of differences remained at a low level. An in-depth layout of differences between the groups was presented in Table 3.

The Kruskal-Wallis tests showed statistically significant minor differences between the respondents' education and their health self-assessment $\left(\mathrm{p}<0.001 ; \eta^{2}>0.3\right)$. Mean values indicate that the respondents with higher education were characterized by a better assessment of QoL and its domains(Tab. 4).

An analogous analysis to the aforementioned one was conducted to check the influence of marital status on QoL in the group researched (Tab. 5). The results of the KruskalWallis test revealed statistical significance $(\mathrm{p}<0.05)$ for overall QoL and overall health, as well as the physical, psychological and social domains. All the measurements of size effect of $\eta^{2}$ differences proved to be quite weak $\left(\eta^{2}>0.3\right)$. As far as mean values of QoL and its domains are concerned, the respondents 
Table 3. Relationship between gender or age and QoL

\begin{tabular}{|c|c|c|c|c|c|c|}
\hline \multirow{2}{*}{ Variable } & \multicolumn{3}{|c|}{ Gender } & \multicolumn{3}{|c|}{ Age } \\
\hline & female & male & $M$-W test & $60-74$ & $\geq 75$ & $M-W$ test \\
\hline OQoL & $\begin{array}{c}M=3.52 \mathrm{SD}=0.63 \\
M e=4.00\end{array}$ & $\begin{array}{c}M=3.44 \mathrm{SD}=0.96 \\
M e=3.00\end{array}$ & $\begin{array}{c}\mathrm{Z}=-0.660 p=0.510 \\
r g=0.05\end{array}$ & $\begin{array}{c}M=3.57 \mathrm{SD}=0.87 \\
M e=4.00\end{array}$ & $\begin{array}{c}M=3.37 \mathrm{SD}=0.67 \\
M e=3.00\end{array}$ & $\begin{array}{c}\mathrm{Z}=-3.635 p<0.001 \\
r g=0.13\end{array}$ \\
\hline ISH & $\begin{array}{c}M=3.33 \mathrm{SD}=0.81 \\
M e=3.00\end{array}$ & $\begin{array}{c}M=3.10 S D=1.08 \\
M e=3.00\end{array}$ & $\begin{array}{c}Z=-2.718 p=0.007 \\
r g=0.12\end{array}$ & $\begin{array}{c}M=3.40 \mathrm{SD}=0.97 \\
\mathrm{Me}=3.00\end{array}$ & $\begin{array}{c}M=3.00 \mathrm{SD}=0.79 \\
M e=3.00\end{array}$ & $\begin{array}{c}Z=-5.545 p<0.001 \\
r g=0.22\end{array}$ \\
\hline PSD & $\begin{array}{c}M=13.23 \mathrm{SD}=2.48 \\
M e=12.67\end{array}$ & $\begin{array}{c}M=13.28 \mathrm{SD}=3.01 \\
M e=13.33\end{array}$ & $\begin{array}{c}\mathrm{Z}=-0.072 p=0.943 \\
r g=-0.01\end{array}$ & $\begin{array}{c}M=13.69 S D=2.80 \\
M e=14.00\end{array}$ & $\begin{array}{c}M=12.56 \mathrm{SD}=2.36 \\
M e=12.00\end{array}$ & $\begin{array}{c}\mathrm{Z}=-5.180 p<0.001 \\
r g=0.21\end{array}$ \\
\hline SOD & $\begin{array}{c}M=14.04 S D=2.35 \\
M e=14.67\end{array}$ & $\begin{array}{c}M=13.96 S D=2.48 \\
M e=13.33\end{array}$ & $\begin{array}{c}\mathrm{Z}=-0.462 p=0.644 \\
r g=0.02\end{array}$ & $\begin{array}{c}M=14.11 S D=2.65 \\
M e=14.67\end{array}$ & $\begin{array}{c}M=13.86 \mathrm{SD}=1.95 \\
M e=13.33\end{array}$ & $\begin{array}{c}\mathrm{Z}=-1.646 p=0.100 \\
r g=0.05\end{array}$ \\
\hline END & $\begin{array}{c}M=14.00 \mathrm{SD}=2.21 \\
M e=14.00\end{array}$ & $\begin{array}{c}M=13.89 S D=2.12 \\
M e=14.00\end{array}$ & $\begin{array}{c}Z=-0.585 p=0.588 \\
r g=0.03\end{array}$ & $\begin{array}{c}M=14.24 \mathrm{SD}=2.38 \\
M e=14.00\end{array}$ & $\begin{array}{c}M=13.53 S D=1.74 \\
M e=13.50\end{array}$ & $\begin{array}{c}Z=-3.399 p<0.001 \\
r g=0.17\end{array}$ \\
\hline
\end{tabular}

M - mean, SD - standard deviation, Me - median, M-W test - Mann-Whitney test

Table 4. Relationship between education and QoL

\begin{tabular}{|c|c|c|c|c|c|}
\hline Variable & Primary & Vocational & Secondary & Higher & $\mathrm{K}-\mathrm{W}$ test \\
\hline \multirow{2}{*}{ OQoL } & $M=3.56(a) S D=0.56$ & $M=3.23 \mathrm{SD}=0.53$ & $M=3.35(a) S D=0.93$ & $\mathrm{M}=4.02 \mathrm{SD}=0.71$ & $H=84.883 p<0.001$ \\
\hline & $\mathrm{Me}=4.00$ & $\mathrm{Me}=3.00$ & $\mathrm{Me}=3.50$ & $\mathrm{Me}=4.00$ & $\eta^{2}=0.14$ \\
\hline \multirow{2}{*}{ ISH } & $M=3.18(a) S D=0.77$ & $\mathrm{M}=2.84 \mathrm{SD}=0.76$ & $M=3.29(a) S D=0.89$ & $\mathrm{M}=3.70 \mathrm{SD}=1.02$ & $H=68.882 p<0.001$ \\
\hline & $\mathrm{Me}=3.00$ & $\mathrm{Me}=3.00$ & $\mathrm{Me}=3.00$ & $\mathrm{Me}=4.00$ & $\eta^{2}=0.12$ \\
\hline \multirow{2}{*}{ PHD } & $M=13.47(a) S D=2.57$ & $M=13.21$ (a) $S D=2.15$ & $M=14.69 S D=2.27$ & $M=16.63 S D=2.11$ & $\mathrm{H}=143.187 \mathrm{p}<0.001$ \\
\hline & $\mathrm{Me}=13.14$ & $\mathrm{Me}=13.14$ & $M e=14.86$ & $\mathrm{Me}=16.57$ & $\eta^{2}=0.24$ \\
\hline \multirow{2}{*}{ PSD } & $M=12.59(a, b) S D=1.99$ & $M=11.79(a) S D=1.98$ & $M=13.30$ (b) $S D=2.55$ & $M=15.27 \mathrm{SD}=2.73$ & $H=119.463 p<0.001$ \\
\hline & $\mathrm{Me}=12.67$ & $\mathrm{Me}=11.33$ & $M e=13.33$ & $\mathrm{Me}=15.33$ & $\eta^{2}=0.20$ \\
\hline \multirow{2}{*}{ SOD } & $M=13.61(a) S D=1.43$ & $M=13.12(a) S D=1.81$ & $M=14.25(b) S D=2.45$ & $M=14.90$ (b) $S D=2.91$ & $H=57.345 p<0.001$ \\
\hline & $\mathrm{Me}=13.33$ & $\mathrm{Me}=13.33$ & $\mathrm{Me}=14.67$ & $\mathrm{Me}=16.00$ & $\eta^{2}=0.10$ \\
\hline \multirow{2}{*}{ END } & $M=13.98(a) S D=1.55$ & $M=13.14 S D=1.59$ & $M=13.78(a) S D=2.40$ & $M=15.27 \mathrm{SD}=1.90$ & $H=85.800 p<0.001$ \\
\hline & $M e=14.50$ & $\mathrm{Me}=12.50$ & $M e=13.50$ & $\mathrm{Me}=14.50$ & $\eta^{2}=0.15$ \\
\hline
\end{tabular}

$\mathrm{M}$ - mean; SD - standard deviation; Me - median; K-W test - Kruskal-Wallis test. Letters $(a, b)$ used to mark lack of differences between mean values.

Table 5. Relationship between marital status and QoL

\begin{tabular}{|c|c|c|c|c|c|}
\hline Variable & Single & Married & Divorced & Widowed & K-W test \\
\hline OQoL & $\begin{array}{c}M=3.70(a) S D=0.76 \\
M e=4.00\end{array}$ & $\begin{array}{c}M=3.68(a) S D=0.44 \\
M e=4.00\end{array}$ & $\begin{array}{c}M=3.21(b) S D=1.11 \\
M e=3.00\end{array}$ & $\begin{array}{c}M=3.18(b) S D=0.67 \\
M e=3.00\end{array}$ & $\begin{array}{c}H=56.586 p<0.001 \\
\eta^{2}=0.10\end{array}$ \\
\hline ISH & $\begin{array}{c}M=3.36(a, b, c) S D=1.03 \\
M e=3.00\end{array}$ & $\begin{array}{c}M=3.34(b, c) S D=0.86 \\
M e=4.00\end{array}$ & $\begin{array}{c}M=3.02(a, b) S D=1.14 \\
M e=3.00\end{array}$ & $\begin{array}{c}M=3.13(a) S D=0.72 \\
M e=3.00\end{array}$ & $\begin{array}{c}H=10.487 p<0.015 \\
\eta^{2}=0.02\end{array}$ \\
\hline PHD & $\begin{array}{c}M=15.57(a, b) S D=2.51 \\
M e=14.86\end{array}$ & $\begin{array}{c}M=14.79(a) S D=2.42 \\
M e=14.86\end{array}$ & $\begin{array}{c}M=14.95(a, b) S D=2.41 \\
M e=15.43\end{array}$ & $\begin{array}{c}M=13.14 S D=2.29 \\
M e=13.14\end{array}$ & $\begin{array}{c}H=64.501 p<0.001 \\
\eta^{2}=0.11\end{array}$ \\
\hline PSD & $\begin{array}{c}M=14.12(a, b) S D=3.09 \\
M e=14.00\end{array}$ & $\begin{array}{c}M=13.44(a, b) S D=2.56 \\
M e=14.00\end{array}$ & $\begin{array}{c}M=13.34(a) S D=2.74 \\
M e=14.00\end{array}$ & $\begin{array}{c}M=12.09 \mathrm{SD}=1.93 \\
M e=12.00\end{array}$ & $\begin{array}{c}\mathrm{H}=39.932 \mathrm{p}<0.001 \\
\eta^{2}=0.07\end{array}$ \\
\hline SOD & $\begin{array}{c}M=14.59(a) S D=2.64 \\
M e=14.67\end{array}$ & $\begin{array}{c}M=14.63(a) S D=2.13 \\
M e=14.67\end{array}$ & $\begin{array}{c}M=12.51(b) S D=2.55 \\
M e=10.67\end{array}$ & $\begin{array}{c}M=13.46(b) S D=1.88 \\
M e=13.33\end{array}$ & $\begin{array}{c}H=66.674 p<0.001 \\
\eta^{2}=0.11\end{array}$ \\
\hline END & $\begin{array}{c}M=14.40 \mathrm{SD}=2.34 \\
M e=14.00\end{array}$ & $\begin{array}{c}M=13.68 \mathrm{SD}=1.80 \\
M e=13.50\end{array}$ & $\begin{array}{c}M=14.00 S D=2.48 \\
M e=14.00\end{array}$ & $\begin{array}{c}M=13.89 S D=2.25 \\
M e=13.50\end{array}$ & $\begin{array}{c}H=5.517 p<0.138 \\
\eta^{2}=0.01\end{array}$ \\
\hline
\end{tabular}

M - mean; SD - standard deviation; Me - median; K-W test - Kruskal-Wallis test.

Letters $(a, b, c)$ used to show lack of differences between mean values. 
who were single gave better assessments. No statistically significant differences were found in the environmental domain. A detailed layout of differences between the groups was shown in Table 5.

\section{DISCUSSION}

To consider seniors' problems, two aspects should be distinguished: functional and emotional. As far as functional problems are concerned, concomitant with the process of aging, they can be resolved by institutional support. In contrast, emotional problems (e.g. a sense of social isolation, loneliness, disturbed family relations) should be solved by non-formalized interactions between a senior and members of his or her social network [31]. Supporting an elderly individual is characterized by greater efficiency if it is provided with the participation of small groups of family members. Family care of a senior results in better outcomes than institutional care, which is reflected in a better perception of QoL [32]. Improvement of emotional state and enhancement of social support in seniors seem to be key actions aimed at the maintenance of a satisfactory level of their QoL. Structural and functional support belong to factors positively influencing health. In cases of isolation, the lack or scarcity of sources of support has been proven to disturb functioning in physical and psychological domains [33-36]. Moreover, social support has a health promoting function by building the sense of being a member of a community. Therefore, individuals receiving support and help from their relatives can be recognized as healthier than those deprived of this support $[37,38]$. Research by Zboina et al. [39] confirmed the existence of dependencies between the QoL and seniors' performance in the physical, psychological and environmental domains. Disturbances of physical functioning, particularly difficulties in walking, constituted a serious impediment to maintaining social contacts, which could cause loneliness and exclusion from the former social life. Furthermore, restricted mobility of the elderly was associated with consequences of a psychological nature, with symptoms of depression. Similarly, in the research by Jaracz et al. [40], the QoL and its dimensions were rated lower by respondents deprived of family support. Despite this, the overall quality of life remained at a satisfactorily high level, which can be explained by positive extra-familial relations. What is more, in one of the works by Grzegorczyk et al. and in the research by Frączak and Stawska [41-42], a lower average assessment of the QoL was observed in respondents not living with their families, in comparison with the control group. The studies indicated a considerably decreased physical function of respondents, which can result from the fact that seniors usually suffer from many diseases and are, or become, incapable of carrying out daily living activities, especially when they can rely on their relatives' assistance. The above-mentioned results coincide with with those of the authors of the current study. Kurowska and Błaszczuk [43], and Wróblewska and Iwaneczko [44] showed that the overall QoL of seniors was at quite a high level similar results were obtained in the current study where the overall QoL was assessed at a considerably good level in both groups. Moreover, the results of the current study are contrary to those obtained by Kurowska and Kajut [45] where the environmental domain was assessed the highest.
The case of seniors dwelling alone presents an unusual situation. According to the structure of the WHOQOL-bref questionnaire, the environmental domain comprises the following elements: financial resources, freedom and safety, healthcare, access to information, possibility of recreation and relaxation, external environment and transportation. High mean values in this domain in the group of individuals living alone can be a consequence of their greater independence and replacement of lost family relations with establishing close relationships with friends or neighbours. The studies by Płaszewska-Żywko et al. [46] confirmed low values of seniors' assessment of their health. This is understandable because of characteristic-of-old-age dependence on help from others resulting from restricted mobility. Results of the current study are similar to those obtained by Kurowska and Kajut [45] where the environmental domain was assessed the highest by respondents living alone. In other studies [41, 4750]; however, a tendency to lower assessment of functioning in the physical domain was confirmed. Besides, in the studies, the domain of social contacts was rated the highest. This is partially substantiated in the current study and other results obtained [51] where the physical domain of QoL was assessed the best. This can be directly connected with the fact that the respondents knew they could rely on the assistance of their relatives or professional caretakers.

The results of the current study correspond with other studies [52] regarding higher assessments of QoL of the respondents living with their families. An essential factor shaping seniors' self-assessment is the place of residence. A fear of changing residence is typical of old age. The elderly find it difficult to adapt to new situations that are usually stressful for them because being rooted in their environment favours maintaining their relationships and creating the sense of safety and being needed. The studies by Liu et al. [53] showed that seniors living alone experience loneliness because of a reduced number of contacts. Predominantly women face this problem as they live alone after their partner's death. This results from the fact that women usually marry men older than themselves and they live longer than males, hence, in their case the probability of living alone is greater. Moreover, widowed women have smaller chances of getting married again. On the other hand, there are men who require help in daily activities earlier than women. Results of some research [41] indicate that a higher assessment of QoL is provided by seniors having partners. The current study also proves that having a partner is commonly known to protect mental health by decreasing the sense of alienation and increasing the sense of belonging. Apart from this, those living with their partners can rely on their help, particularly in old age. In contrast, seniors living alone are often forced to deal with their problems and daily activities by themselves. They struggle with isolation resulting from a decrease in sources of support. Assistance provided by formal caretakers to maintain social contacts at a satisfactory level can prove to be a crucial factor preventing emotional disorders. Group support programmes can diminish loneliness and positively affect the perception of social support, and in this way lead to the improvement of QoL $[54,55]$. The research by Zboina et al. [39] confirmed that females were characterized by a higher assessment of overall health than males, which can be explained by the fact that women conduct healthier, namely health promoting lifestyles, and more frequently are counselled on their health. 
In the current study, the respondents were differentiated in terms of their age, and a similar observation was provided by Drageset et al. [56]. Significant differences between age and QoL as well as its domains were found among the younger respondents aged 60-74 years old. The study by Cordeiro et al. [57] showed a similar trend - older respondents aged 80 and over were characterized by a lower assessment of QoL, which can be associated with progressive diseases, lack of independence and decreased activity. The above is contradicted in the research by Kurowska and Kajut [45] where an increase in the mean values of QoL was observed in respondents older than 75 .

As far as marital status is concerned, this correlated with QoL at a statistically significant level excluding the environmental domain. In the current study, the respondents who were single assessed the domains of QoL higher. The same was observed in the research by Hedayati et al. [58], which can be connected to the fact of being more independent than married respondents or those being in relationships. Furthermore, single respondents showed greater independence, hence resistance to adversities; thus, a change of their environment did not lead to a decrease in their QoL and its components. The highest assessments provided by single respondents were surprising because having a partner is known to have a protective influence on mental health as it decreases the sense of alienation and increases the sense of belonging. Moreover, respondents in relationships can rely on their partners' help, which is particularly important in old age. On the other hand, the single or widowed are forced to cope with daily problems on their own and have to contend with loneliness and decreased sources of support. Different results were obtained by Grzegorczyk et al. [41], de Belvis et al. [59] and Garcia et al. [60] because respondents in relationships were characterized by a better assessment of the social domain than those living alone. This is confirmed by the protective influence of the support network on QoL of seniors who are surrounded by their close relatives. Apart from the sense of safety, the support network provides a sense of integration and belonging to a community.

The level of education correlated positively with QoL in the group of respondents living with their families and alone. This is confirmed in the research by Drageset et al. [56] and Hedayati et al. [58] in which an increasing tendency of QoL assessment was noticed, together with an increase in a level of education. Similar findings were presented by Lou [61]. The better QoL stated by well-educated respondents is usually explained by a higher level of knowledge and pro-health awareness. Moreover, well-educated individuals usually have higher professional status and income.

\section{CONCLUSIONS}

1. A family status of a senior influences his or her quality of life.

2. Seniors living with their families experience better life conditions, which is reflected in their better performance in the physical, psychological and social domains.

3. Loneliness, frequently accompanying old age, leads to deterioration of the quality of life.

4. Demographic factors can be acknowledged as modifiers of the QoL of seniors.

\section{REFERENCES}

1. Lina XJ, Linb IM, Fan SY. Methodological issues in measuring healthrelated quality of life. Tzu Chi Med J. 2013; 25(1): 8-12.

2. Farquhar M. Elderly peoples's definitios of quality of life. Soc Sci Med. 1995; 41(10): 1439-1446.

3. Sokolnicka H, Mikuła W. Medycyna a pojęcie jakości życia. Med Rodz. 2003; 3-4: 126-128.

4. Kukielczak A. Rozwój zainteresowania w naukach medycznych badaniami nad jakością życia. Przegl Epidemiol. 2012; 66(3): 539-545.

5. Juczyński Z. Health-related quality of life: theory and measurement. Folia Psychologica. 2006; 10: 3-15.

6. Sichipper H. Quality of life: principles of the clinical paradig. J Psychosoc Oncol. 1990; 9: 171-185.

7. Schipper H. Guidelines and caveats for quality of life measurement in clinical practice and research. Oncology (Williston Park). 1990; 4(5): 51-57.

8. Kochman D. Koncepcje teoretyczne jakości życia. Piel Pol. 2008; 1(27): 55-58.

9. World Health Organization. The Constitution of the World Health Organization. WHO. Switzerland, Geneva 1948.

10. Stelcer B. Jakość życia jako pojęcie subiektywne i wielowymiarowe. Piel Pol. 2001; 2(12): 227-233.

11. Gruszczyński W, Goc S. Pojęcie jakości życia w medycynie. Kwartalnik Ortopedyczny. 2004; 3: 151-155.

12. Wnuk M, Marcinkowski JT. Jakość życia jako pojęcie pluralistyczne o charakterze interdyscyplinarnym. Probl Hig Epidemiol. 2012; 93(1): 21-26.

13. Szewczyczak M, Stachowska M, Talarska D. Ocena jakości życia osób w wieku podeszłym - przegląd piśmiennictwa. Now Lek. 2012; 81(1): 96-100.

14. Guyatt GH, Ferrans CE, Halyard MY, Revicki DA, Symonds TL, Varricchio CG et al. Jakość życia zależna od stanu zdrowia - od badań klinicznych do praktyki lekarskiej. Med Dypl. 2008; 17(4): 24-38.

15. Saxena S, Orley J. Quality of life assessement. The World Health Organization perspective. Eur Psychiatry. 1997; 12(3): 263-266.

16. Low G, Molzahn AE. Predictors of quality of life in old age: a crossvalidation study. Res Nurs Health. 2007; 30(2): 141-150.

17. Fereshteh Niknam, Alireza Homayouni, Arsalan Khan Mohammadi: Relationship among social support, quality of life and loneliness of the elderly. International Journal of Advanced Biotechnology and Research, 2016; 7(3): 1365-1373

18. Garousi S, Safizadeh H, Samadian F. The Study of Relationship between Social Support and Quality of Life among Elderly People in Kerman. Jundishapur Scientific Medical Journal. 2012; 11: 303-315.

19. L.A. Theeke, J. Mallow: Loneliness and Quality of Life in Chronically Ill Rural Older Adults: Findings from a pilot study. Am J Nurs. 2013; 113(9): 28-38.

20. Yang K, Victor CR. The prevalence of and risk factors for loneliness among older people in China. Ageing Soc. 2008; 28(3): 305-327.

21. Borgil G, Jakobsson U, Edberg A and Hallberg I. Older people in Swedenwith various degrees of present quality of life: their health, social support, everyday activities and sense of coherence. Health Soc Care Community 14: 36-146, 2006.

22. Cacioppo JT, Hawkley LC, Norman GJ, et al. Social isolation. Ann N Y Acad Sci 2011;1231:17-22; Grenade L, Boldy D. Social isolation and loneliness among older people: issues and future challenges in community and residential settings. Aust Health Rev. 2008; 32: 468-478.

23. Victor CR, Scambler SJ, Bowling ANN, et al. The prevalence of, and risk factors for, loneliness in later life: a survey of older people in great Britain. Ageing Soc 2005; 25: 357-375.

24. Dugan E, Kivett VR. The importance of emotional and social isolation to loneliness among very old rural adults. Gerontologist. 1994; 34(3): 340-346.

25. Tabali M, Ostermann T, Jeschke E, Dassen T, Heinze C. The Relationship between health-related quality of life and care dependency among nursing home residents in Germany: a longitudinal study. J Gerontol Geriatr Res. 2015; 4(5): 1-6.

26. Jakobsson U, Hallberg IR. Loneliness, fear, and quality of life among elderly in Sweden: a gender perspective. Aging Clin Exp Res. 2005; 17(6): 494-501.

27. The WHOQOL Group. The World Health Organization Quality of Life Assessment (WHOQOL): development and general psychometric properties. Soc Sci Med. 1998; 46(12): 1569-1585.

28. The WHOQOL Group. Development of The World Health Organization WHOQOL-BREF Quality of Life assessment. Psychol Med. 1998; 28(3): 551-558. 
29. Jaracz K, Kalfoss M, Górna K, Bączyk G. Quality of life in Polish respondents: psychometric properties of the Polish WHOQOL-Bref. Scand J Caring Sci. 2006; 20(3): 251-260.

30. Jaracz K, Wołowicka L, Kalfoss M. Quality of life in Polish respondents. Qual Life Res. 1999; 8(7): 565

31. Kawczyńska-Butrym Z. Problemy opieki nad człowiekiem starszym obszary pomocy i wsparcia. Pr Soc. 1999; 4: 10-26.

32. Kujawska J. Organizacja i zarządzanie opieką nad osobami starszymi. Zeszyty Naukowe Uniwersytetu Szczecińskiego - Finanse, Rynki Finansowe, Ubezpieczenia. 2015; 74(1): 709-722.

33. Health Quality Ontario. Social isolation in community-dwelling seniors: an evidence-based analysis. Ont Health Technol Assess Ser. 2008; 8(5): 1-49.

34. Uchino BN, Carlisle M, Birmingham W, Vaughn AA. Social support and the reactivity hypothesis: conceptual issues in examining the efficacy of received support during acute psychological stress. Biol Psychol. 2011; 86(2): 137-142.

35. Uchino BN, Bowen K, Carlisle M, Birmingham W. Psychological pathways linking social support to health outcomes: a visit with the "ghosts" of research past, present, and future. Soc Sci Med. 2012; 74(7): 949-957.

36. Wang HH, Wu SZ, Liu YY. Association between social support and health outcomes: a meta-analysis. Kaohsiung J Med Sci. 2003; 19(7): 345-351.

37. Łuszczyńska A, Cieślak R, Maśliński W, Ziółkowska M, JędrykaGóral A. Stres i wsparcie społeczne: zależności z obszaru psychoneuroimmunologii. Psychologia-Etologia-Genetyka. 2001; 3-4: 13-32.

38. DeLongis A, Folkman S, Lazarus RS. The impact of daily stress on health and mood: psychological and social resources as mediators. J Pers Soc Psychol. 1988; 54(3): 486-495.

39. Zboina B, Kulik TB, Pacian A, Rudnicka-Drożak E. Biopsychosocial factors shaping perception of quality of life of elderly people in longterm care. Pol J Environ Stud. 2006; 15(2a): 940-944.

40. Jaracz K, Woźna M. Subiektywna ocena zdrowia i jakości życia osób starszych. Piel Pol. 2001; 2(12): 262-269.

41. Grzegorczyk J, Kwolek A, Bazarnik, Szeliga KE, Wolan A. Jakość życia osób mieszkających w domach pomocy społecznej i słuchaczy uniwersytetu trzeciego wieku. Przegląd Medyczny Uniwersytetu Rzeszowskiego. 2007; 3: 225-233.

42. Frączak B, Stawska B. Pensioners' quality of life in social care houses. Roczniki Pomorskiej Akademii Medycznej w Szczecinie. 2007; 53(1): 98-103.

43. Kurowska K, Błaszczuk W. Wpływ wsparcia na jakość życia mieszkańców Domu Pomocy Społecznej. Psychogeriatria Pol. 2013; 10(1): 33-40.

44. Wróblewska I, Iwaneczko A. Jakość życia pensjonariuszy Domu Pomocy Społecznej „Złota Jesień” w Raciborzu - badania własne. Fam Med Prim Care Rev. 2012; 14(4): 573-576.

45. Kurowska K, Kajut A. Samoocena jakości życia osób starszych na przykładzie pensjonariuszy Domu Pomocy Społecznej (DPS). Psychogeriatria Pol. 2011; 8(2): 55-62.
46. Płaszewska-Żywko L, Brzuzan P, Malinowska-Lipień I, Gabryś T. Sprawność funkcjonalna u osób w wieku podeszłym w domach pomocy społecznej. Probl Hig Epidemiol. 2008; 89(1): 62-66.

47. Hall S, Opio D, Dodd RH, Higginson IJ. Assessing quality-of-life in older people in care homes. Age Ageing. 2011; 40(4): 507-512.

48. Onunkwor OF, Al-Dubai SA, George PP, Arokiasamy J, Yadav H, Barua A, et al. A cross-sectional study on quality of life among the elderly in non-governmental organizations' elderly homes in Kuala Lumpur. Health Qual Life Outcomes. 2016; 14: 6.

49. Schenk L, Meyer R, Behr A, Kuhlmey A, Holzhausen M. Quality of life in nursing homes: results of a qualitative resident survey. Qual Life Res. 2013; 22(10): 2929-2938.

50. Tseng SZ, Wang RH. Quality of life and related factors among elderly nursing home residents in Southern Taiwan. Public Health Nurs. 2001; 18(5): 304-311.

51. Tabali M, Ostermann T, Jeschke E, Dassen T, Heinze C. The Relationship between health-related quality of life and care dependency among nursing home residents in Germany: a longitudinal study. J Gerontol Geriatr Res. 2015; 4(5): 1-6.

52. Van Dussen DJ, Morgan LA. Gender and informal caregiving in CCRCs: primary caregivers or support networks? J Women Aging. 2009; 21(4): 251-265.

53. Liu N, Zeng L, Li Z, Wang J. Health-related quality of life and long-term care needs among elderly individuals living alone: a cross-sectional study in rural areas of Shaanxi Province, China. BMC Public Health. 2013; 13(1): 313-319.

54. Strine TW, Chapman DP, Balluz L, Mokdad AH. Health-related quality of life and health behaviors by social and emotional support. Their relevance to psychiatry and medicine. Soc Psychiatry Psychiatr Epidemiol. 2008; 43(2): 151-159.

55. Rodrigues MMS, de Jong Gierveld J, Buz J. Loneliness and the exchange of social support among older adults in Spain and the Netherlands. Ageing Soc. 2013; 34(2): 330-355.

56. Drageset J, Natvig GK, Eide GE, Clipp EC, Bondevik M, Nortvedt MW, Nygaard HA. Differences in health-related quality of life between older nursing home residents without cognitive impairment and the general population of Norway. J Clin Nurs. 2008; 17(9): 1227-1236.

57. Cordeiro LM, de Lima Paulino J, Peixoto Bessa ME, Borges CL, Pedrosa Leite SF. Quality of life of frail and institutionalized elderly. Acta Paul Enferm. 2015; 28(4): 361-366.

58. Hedayati HR, Hadi N, Mostafavi L, Akbarzadeh A, Montazeri A. Quality of life among nursing home residents compared with the elderly at home. Shiraz E-Med J. 2014; 15(4): e22718.

59. de Belvis AG, Avolio M, Spagnolo A, Damiani G, Sicuro L, Cicchetti A et al. Factors associated with health-related quality of life: the role of social relationships among the elderly in an Italian region. Public Health. 2008; 122(8): 784-793.

60. García EL, Banegas JR, Pérez-Regadera AG, Cabrera RH, RodríguezArtalejo F. Social network and health-related quality of life in older adults: a population-based study in Spain. Qual Life Res. 2005; 14(2): 511-520.

61. Lou VWQ. Life satisfaction of older adults in hong kong: the role of social support from grandchildren. Soc Indic Res. 2010; 95(3): 377-391. 